\title{
Реваскуляризація нижніх кінцівок в умовах високого ризику розвитку реперфузійних ускладнень
}

\author{
О. Б. Колотило ${ }^{1}$, І. К. Венгер ${ }^{2}$, С. Я. Костів ${ }^{2}$, І. М. Козловська ${ }^{1}$
}

${ }^{1}$ Буковинський державний медичний університет, м. Чернівці,

${ }^{2}$ Тернопільський державний медичний університет імені І. Я. Горбачевського МОЗ України

\section{Revascularization of lower extremities in conditions of high risk for development of reperfusion complications}

\author{
O. B. Kolotylo ${ }^{1}$, I. K. Wenger ${ }^{2}$, S. Ya. Kostiv ${ }^{2}$, I. M. Kozlovska ${ }^{1}$ \\ ${ }^{1}$ Bukovyna State Medical University, Chernivtsi, \\ ${ }^{2}$ Gorbachevskyi Ternopil State Medical University
}

\section{Реферат}

Мета. Попередження розвитку реперфузійних ускладнень (Ру) шляхом застосування прийомів та хірургічних втручань у складі реваскуляризуючого оперативного лікування атеросклеротичної багаторівневої оклюзії магістральних артерій нижніх кінцівок (НК) у пацієнтів після комплексної передопераційної підготовки з високим ризиком розвитку РУ. Матеріали і методи. Реваскуляризуюче оперативне лікування проведене 46 пацієнтам із різними видами оклюзії судин НК та високим ризиком розвитку РУ.

Результати. У ході аналізу перебігу періопераційного періоду у 7 (15,2\%) пацієнтів діагностовано прояви реперфузійного синдрому. У 5 з них кровоток по артеріальному руслу ішемізованої НК відновили одномоментно, у 1 - виконали тільки аорто/клубово-стегнове алошунтування, у 1 - аорто/клубово-стегнове алошунтування доповнили стегно-дистальним аутовенозним шунтуванням на 2-гу добу після першого оперативного втручання.

Висновки. Патогенетично обгрунтована передопераційна підготовка та застосування прийомів і хірургічних втручань у складі реваскуляризуючого оперативного лікування атеросклеротичної багаторівневої оклюзії магістральних артерій НК в умовах високого ризику розвитку РУ дали можливість у 39 (84,8\%) пацієнтів попередити ускладнення.

Ключові слова: реперфузійні ускладнення; реваскуляризація; атеросклеротична оклюзія.

Abstract

Objective. Prophylaxis of the reperfusion complications (RC) occurrence, using application of measures and surgical interventions in a content of revascularization operative treatment of atherosclerotic multilevel occlusion of the lower extremities main arteries in patients after complex preoperative preparation with high risk of the RC occurrence.

Materials and methods. Revascularization operative intervention was conducted in 46 patients, suffering various occlusions of the lower extremities vessels and high risk of the RC occurrence.

Results. While analyzing the perioperative period course in 7 (15.2\%) patients, the signs of RC were diagnosed. In 5 of them a blood flow along arterial bed of the ischemized lower extremities was restored in one stage, in 1 - the aorto/ischio-femoral alloshunting was conducted only, and in 1 - aorto/ischio-femoral alloshunting on the second day after first operative intervention. Conclusion. Pathogenetically substantiated preoperative preparation, application of measures and surgical interventions in a content of the revascularization operative treatment for atherosclerotic multilevel occlusion of the lower extremities main arteries in conditions of high risk for the RC occurrence gave the possibility to prevent the complications in 39 (84.8\%) patients.

Keywords: reperfusion complications; revascularization; atherosclerotic occlusion.

Незважаючи на очевидні досягнення судинної хірургії, частота ускладнень після реконструктивних операцій на аорті і магістральних артеріях НК становить 2,7 - 3,2\% [1]. Однією з причин несприятливих наслідків реконструкції аорто-стегно-підколінного сегмента є розвиток РУ [2]. Запропоновано немало методів профілактики і лікування реперфузійно-ішемічних ускладнень: прекондиціонування [3], інтраопераційна контрольована реперфузія [4], до- і післяопераційна детоксикаційна терапія [5], застосування еферентних методів детоксикації [6]. Але більшість їх спрямована на корекцію метаболічних процесів у тканинах або ж уже розвинутих ускладнень. Механізм розвитку РУ запускається в момент відновлення кровотоку в ішемізованій НК [7]. Отже, необхідно запропонувати методи, які будуть складовою частиною реваскуляризуючого хірургічного втручання і впливатимуть на корекцію кров'яного потоку в магістральних артеріях НК.

Мета дослідження: попередити розвиток РУ шляхом застосування прийомів та хірургічних втручань у складі реваскуляризуючого оперативного лікування атеросклеротичної багаторівневої оклюзії магістральних артерій НК у пацієнтів після комплексної передопераційної підготовки з високим ризиком розвитку РУ.

\section{Матеріали і методи дослідження}

Реваскуляризуюче оперативне лікування проведене 46 паціентам із високим ризиком розвитку РУ. У 32 пацієнтів виявили різні варіанти атеросклеротичної оклю- 
зіі аорто-стегнового сегмента, у 18 з них - стенотичнооклюзивний процес стегно-підколінного сегмента; у 14 - атеросклеротичну оклюзію клубового сегмента, у 7 з них - стенотично-оклюзивний процес стегно-підколінного сегмента.

У всіх пацієнтів щодо НК із високим ризиком розвитку РУ встановлено IIIA, IIIB, IV ступінь хронічної артеріальної недостатності (ХАН), щодо контрлатеральної НК - IIA, IIB ступінь ХАН. Для встановлення ступеня ішемічного ураження НК застосовували модифіковану класифікацію R. Fontaine з урахуванням критеріїв Європейської робочої групи (1992).

Ризик розвитку РУ оцінювали за підвищеним вмістом у сироватці крові C-реактивного білка - $(2,04 \pm 0,38)$ г/л $(\mathrm{p}<0,05) ;$ лактату - $(3,43 \pm 9,45)$ ммоль $/ л(\mathrm{p}<0,001)$; за ступенем синдрому ендогенної інтоксикації, вираженої лейкоцитарним індексом інтоксикації (ЛII) - (1,66 0 0,29) од. ( $<<0,05)$; за рівнем спонтанного (ОВНс) і стимульованого (OBH E.coli) «оксидантного вибуху» нейтрофілів - відповідно $(0,49 \pm 0,11)$ г/л (p > 0,05), $(5,59 \pm 1,12)$ г/л (р $>0,05)$; за рівнем спонтанного (ОВМс) і стимульованого (OBM E.coli) «Оксидного вибуху» моноцитів - відповідно $(0,03 \pm 0,02)$ г/л $(\mathrm{p}>0,05),(0,35 \pm 0,03)$ г/л $(\mathrm{p}>0,05)$.

Передопераційна підготовка пацієнтів, крім препаратів для покращення реологічного стану крові, включала покращення мікроциркуляції, пролонговану епідуральну анестезію, один-два сеанси лейкаферезу, довенне введення рефортану і корветину.

Реваскуляризацію у пацієнтів із високим ризиком розвитку РУ розпочинали з катетеризації загальної стегнової артерії НК, щодо якої підозрювали розвиток РУ. Внутрішньоартеріально протягом часу виконання операції вводили 100 мл 0,03\% розчину гіпохлориду натрію і 0,5 г кверцетину у 100 мл фізіологічного розчину.

Реваскуляризацію у пацієнтів із високим ризиком розвитку РУ виконували, застосовуючи ряд прийомів та методів хірургічного втручання, основною метою яких було сповільнення надходження ударної хвилі кровотоку в ішемізовану НК.

Декліпування аорти визначає перебіг відновлення кровотоку по магістральних артеріях НК. При аорто-біфеморальному алошунтуванні/протезуванні слід відновлювати кровоток по браншах алошунта/протеза почергово: спочатку по бранші непроблемної НК, потім - по бранші НК, щодо якої очікується розвиток РУ. Така послідовність відновлення кровотоку по браншах алопротеза дає змогу вдвічі знизити силу ударної хвилі кровотоку по артеріальному руслу проблемної НК.
При багаторівневому атеросклеротичному оклюзивному процесі артеріального русла НК: аорто/клубовостегновий і стегно-підколінний сегменти, де була підозра розвитку РУ, виконували тільки аорто/клубово-стегнове алошунтування. Операція в такому об'ємі дає можливість запобігти поширенню ударної хвилі кровотоку на дистальні сегменти НК.

При оклюзії II, III типу за О. С. Ніконенком стегно-підколінного сегмента тільки аорто/клубово-стегнове алошунтування недостатне через неповноцінну функцію глибокої стегнової артерії (ГСА). У хворих із вказаними типами оклюзії стегно-підколінного сегмента блокуються анастомози гілок ГСА з гілками підколінної артерії та артеріями гомілки, тому аорто/клубово-стегнове алошунтування доповнювали стегно-дистальним аутовенозним шунтуванням, яке у разі наявності загрози розвитку РУ виконували на 2-гу - 3-тю добу після першого оперативного втручання. Саме в цей період пульсова систолічна швидкість (ПСШ) та індекс резистентності (IP) на рівні ГСА сягає $(23,2 \pm 1,51) \mathrm{cm} / \mathrm{c}$ і $(0,41 \pm 0,29)$ у.о. відповідно, а на рівні тібіоперинеального стовбура (ТПС) вони коливаються в межах $(17,1 \pm 3,11)$ см/с і $(0,39 \pm 0,11)$ у. о. відповідно (див. таблицю).

У 23\% пацієнтів, які мають високий ризик розвитку РУ, з однобічною атеросклеротичною оклюзією клубовостегнового сегмента виявляють стенотичний атеросклеротичний процес (звуження просвіту судин на 63 - 88\%) контрлатерального клубово-стегнового сегмента (ПСШ по загальній клубовій артерії $180-200$ см/с), який створює високий периферійний судинний опір. У разі відновлення плину крові тільки по оклюзованому клубовостегновому сегменту потік крові з аорти перерозподіляється в напрямку русла з низьким периферичним судинним опором, створючи сприятливі умови для формування тромботичного процесу в судинному руслі контрлатеральної НК. Враховуючи вказані обставини, з метою попередження формування тромботичного процесу в судинному руслі контрлатеральної НК, а також зниження у 2 рази сили ударної хвилі кровотоку по артеріальному руслу проблемної НК при однобічній атеросклеротичній оклюзії клубово-стегнового сегмента і стенозі контрлатерального клубового сегмента (ПСШ $180-200$ см/с) слід виконувати двобічне аорто-біфеморальне алошунтуваня (Пат. України на корисну модель № 115930).

\section{Результати}

3 дотриманням наведених принципів реконструкції аорто-стегно-підколінного сегмента оперовано 46 па-

Величини ПСШ та IP у оперованих пацієнтів ( $\overline{\mathbf{x}} \pm \mathbf{m})$

\begin{tabular}{|c|c|c|c|c|}
\hline \multirow[t]{2}{*}{ Параметри } & \multicolumn{2}{|c|}{ ПСШ, cm/c } & \multicolumn{2}{|c|}{ IP, y.o. } \\
\hline & ГCA & ТПС & ГCA & ТПС \\
\hline Норма & $52,6 \pm 11,3$ & $45,5 \pm 7,32$ & $0,89 \pm 0,05$ & $0,82 \pm 0,03$ \\
\hline Вихідний рівень & $49,1 \pm 4,7$ & $39,8 \pm 3,71$ & $0,61 \pm 0,27$ & $0,51 \pm 0,15$ \\
\hline \multicolumn{5}{|l|}{ Після операції, доба } \\
\hline 1-ша & $53,7 \pm 6,12$ & $38,9 \pm 2,80$ & $0,58 \pm 0,19$ & $0,50 \pm 0,08$ \\
\hline 2-га & $43,4 \pm 4,83$ & $27,3 \pm 2,42$ & $0,53 \pm 0,22$ & $0,43 \pm 0,06$ \\
\hline 3-тя & $23,2 \pm 1,51$ & $17,1 \pm 3,11$ & $0,41 \pm 0,29$ & $0,40 \pm 0,11$ \\
\hline
\end{tabular}


цієнтів із високим ризиком розвитку РУ. У 14 з них кровоток відновлено одномоментно по артеріальному руслу ішемізованої НК, у 15 - виконане тільки аорто/клубово-стегнове алошунтування, у 17 - аорто/клубово-стегнове алошунтування доповнили стегно-дистальним аутовенозним шунтуванням на 2-гу-3-тю добу після першого оперативного втручання.

\section{Обговорення}

У ході аналізу перебігу періопераційного періоду прояви реперфузійного синдрому діагностовано у 7 (15,2\%) пацієнтів, з них у 5 кровоток по артеріальному руслу ішемізованої НК відновлено одномоментно, у 1 - виконано тільки аорто/клубово-стегнове алошунтування, у 1 - аорто/клубово-стегнове алошунтування доповнене стегнодистальним аутовенозним шунтуванням на 2-гу добу після першого оперативного втручання.

Найбільш частими були ускладнення, що мали відношення до порушення ритму і провідності серцевого м'яза (5 спостережень) та розвинулись на етапі завершення хірургічних маніпуляцій на магістральних артеріях.

Одним із проявів реперфузійного синдрому є ураження нирок. Минущу ниркову недостатність (рівень креатиніну більше 0,13 ммоль/л) діагностували у 2 пацієнтів. Варто відмітити, що минуща ниркова недостатність виникає у 35\% хворих після оперативного втручання на аорто-клубовому сегменті. Основним патогенетичним фактором ураження нирок є гіпоксія ниркової тканини, викликана перерозподілом кровотоку, і зміна кисневотранспортної функції крові. Додатково до ураження нирок призводить пошкоджуючий вплив метаболітів перекисного окислення ліпідів, компонентів системи комплементу, що активуються в умовах реперфузії артеріального русла НК.

\section{Висновки}

Патогенетично обгрунтована передопераційна підготовка та застосування прийомів і хірургічних втручань у складі реваскуляризуючого оперативного лікування атеросклеротичної багаторівневої оклюзії магістральних артерій НК, пов'язаної з високим ризиком розвитку реперфузійних та тромботичних ускладнень, дали можливість попередити ці ускладнення у 39 (84,8\%) пацієнтів і знизити частоту ускладнень у вигляді порушення ритму і провідності серцевого м'яза, діагностованого у 5 (10,9\%) пацієнтів, і минущої ниркової недостатності, діагностованої у 2 (4,6\%) пацієнтів.

\section{References}

1. Nikul'nikov PI, Bycaj AN, Ratushnjuk AV, Liksunov AV. Osobennosti hirurgicheskoj taktiki pri mnogourovnevyh okkljuzionno-stenoticheskih porazhenijah bedrenno-bercovogo arterial'nyh segmentov. Harkivs'ka hirurgichna shkola. 2013;3:148-51. [In Russian].

2. Marshalov DV, Petrenko AP, Glushach IA. Reperfuzionnyj sindrom ponjatie, opredilenie, klassifikacija. Patologija krovoobrashhenija i kardiohirurgija. 2008;3:67-72. [In Russian].

3. Kabaroudis A, Gerassimidis T, Karamanos D. Metabolic alteration of skeletal muscle tissue after prolonged acute ischemia and reperfusion (In Process Citation). J Invest Surg. 2003;16(4):219-28.

4. Saita Y, Yokoyama K, Nakamura K, Itoman M. Protective Effect of Preconditioning Against Ischemia-Induced Reperfusion Injury of Sckeletal Muscle How Many Preconditioning are Appropriate? British Journal of Plastic Surgery. 2002;55(3):241-5.

5. Kuznecov MR, Koshkin VM, Komov KV. Sovremennye aspekty diagnostiki, profilaktiki i lechenija reperfuzionnogo sindroma. Angiologija i sosudistaja hirurgija. 2006;1:133-43. [In Russian].

6. Venher IK, Yakymchuk OIa, Zarudna OI. Korektsiia eferentnoiu terapiieiu systemnoi zapalnoi vidpovidi u khvorykh na obliteruiuchyi ateroskleroz arterii nyzhnikh kintsivok. Shpytalna khirurhiia. 2010;1:83-6. [In Ukrainian].

7. Kalinin RE, Pshennikov AS, Suchkov IA. Realizacija ishemii i reperfuzii v hirurgii magistral'nyh arterij nizhnih konechnostej. Novosti hirurgii. 2015;23(1):51-6. [In Russian] 